DIW BERLIN

Discussion Papers

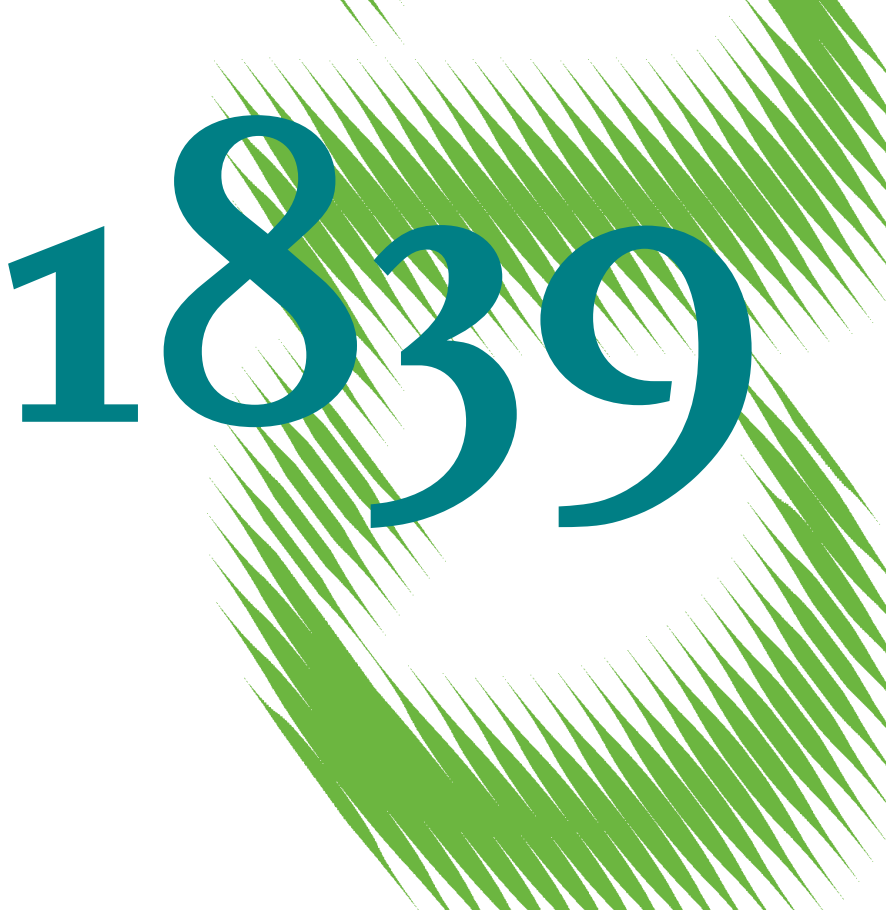

Does Social Policy through Rent Controls Inhibit New Construction? Some Answers from Long-Run Historical Evidence 
Opinions expressed in this paper are those of the author(s) and do not necessarily reflect views of the institute.

IMPRESSUM

(C) DIW Berlin, 2020

DIW Berlin

German Institute for Economic Research

Mohrenstr. 58

10117 Berlin

Tel. +49 (30) $89789-0$

Fax +49 (30) $89789-200$

http://www.diw.de

ISSN electronic edition 1619-4535

Papers can be downloaded free of charge from the DIW Berlin website:

http://www.diw.de/discussionpapers

Discussion Papers of DIW Berlin are indexed in RePEc and SSRN:

http://ideas.repec.org/s/diw/diwwpp.html

http://www.ssrn.com/link/DIW-Berlin-German-Inst-Econ-Res.html 


\title{
Does social policy through rent controls inhibit new construction? Some answers from long-run historical evidence ${ }^{\text {th }}$
}

\author{
Konstantin A. Kholodilin ${ }^{\mathrm{a}, \mathrm{b}}$, Sebastian Kohl ${ }^{\mathrm{c}, \mathrm{d}}$ \\ ${ }^{a}$ DIW Berlin, Mohrenstraße 58, 10117, Berlin, Germany \\ ${ }^{b}$ NRU HSE, Kantemirovskaya ul., 3, 194100, St. Petersburg, Russia \\ ${ }^{c}$ Max-Planck-Institut für Gesellschaftsforschung, Paulstraße 3, 50676, Cologne, Germany \\ ${ }^{d}$ Center for European Studies, Harvard
}

\begin{abstract}
The (re-)introduction of rent regulation in the form of rent controls, tenant protection or supply rationing is back on the agenda of policymakers in light of rent inflation in many global cities. While rent control as social policy promises short-term relief, economists point to their negative long-run effects on new construction. This paper present long-run data on both rent regulation and housing construction for 16 developed countries (1910-2017) and 44 developing countries since the 1980s to confirm the economists' view generally, albeit with certain reservations. The negative effect of regulation can be offset by exemptions for new construction, by compensating government construction and by a flight of new construction into the owner-occupied sector. The overall magnitude of the effect is therefore not as high as expected and shows non-linearities. But, although rent control is usually introduced with good social-policy intentions, it generally risks to crowd out its object of regulation through inhibiting new construction.
\end{abstract}

Keywords: Residential construction, rent control, tenure security, housing rationing, panel data model.

JEL codes: C23, O18, R38.

\footnotetext{
The authors confirm that the paper involves no interest conflicts.
} 


\section{Contents}

1 Introduction 1

2 Determinants of residential construction 3

3 Data $\quad 5$

3.1 Housing construction intensity . . . . . . . . . . . . . . . 5

3.2 Control variables . . . . . . . . . . . . . . . . . . . . . . 6

3.3 Regulation indices . . . . . . . . . . . . . . . . . 6

$\begin{array}{lll}4 & \text { Econometric methodology } & 7\end{array}$

$\begin{array}{llr}5 & \text { Results } & 8\end{array}$

5.1 Descriptive findings . . . . . . . . . . . . . . . . . . 8

5.2 Multivariate estimations . . . . . . . . . . . . . . . . . . . 8

6 Discussion and conclusion $\quad 11$

$\begin{array}{ll}\text { Literature } & 13\end{array}$

$\begin{array}{lr}\text { Figures and tables } & 16\end{array}$ 


\section{List of Tables}

1 Literature explaining construction activity . . . . . . . . . . . . . 16

2 List of countries, for which regulation indices are constructed . . . . . . . . 17

3 Description of variables used in the analysis . . . . . . . . . . 18

4 Estimation results of panel data model: all countries, whole period . . . . . . . . 19

5 Estimation results of panel data model: all countries, 1960-2017 . . . . . . . . . 20

6 Estimation results of panel data model: developed countries, whole period . . . 21

7 Estimation results of panel data model: developed countries, 1960-2017 . . . . . 22

\section{List of Figures}

1 Rent regulations by legal origin . . . . . . . . . . . . . . . . . 23

2 Construction and intensity rent control by legal origin . . . . . . . . . . . . 24

3 Availability of data for all countries . . . . . . . . . . . . . . . . . 25

4 Availability of data for developed countries . . . . . . . . . . . . . 26

5 Impact of rent control on residential construction intensity . . . . . . . . . . 27 


\section{Introduction}

Long thought to be a relic of the past, rent control and other measures in protection of urban tenants are back on the political agenda in a wide range of countries in Europe and beyond. Even if the move towards homeownership has made owner-occupying household the majority in almost all European countries and even more so worldwide, many European cities remain dominated by tenant majorities. They still make up an important constituency whcih protests for rent regulation as a form of social policy. Scholars of housing and social policy, by contrast, still focus predominantly on social housing or homeownership as dominant segments in the housing market. But recent years have experienced a surge in rental market regulation intensity. Especially, in 2019, several countries and states have introduced new or invigorated measures to keep the halt on rent increases. For example, in February 2019, the authorities of the state Oregon imposed upper bounds on the rent increases of CPI growth rate plus 7\%. ${ }^{1}$ Similarly, in Catalonia (Spain) in May 2019, a decree-law was issued capping initial rents for dwellings whose surface does not exceed $150 \mathrm{~m}^{2}$ located in areas having a tense housing market at the reference rent for similar dwellings in the neighborhood $+10 \%$. Simultaneously rent increases were pegged to the index of competitiveness recovery of Spain with respect to the European Monetary Union. ${ }^{2}$ In June 2019, the red-red-green Senate of Berlin (Germany) decided to design a law, according to which a Mietendeckel (literally meaning "rental lid") would be introduced leading to a rent freeze for the next five years, providing even for a possibility to cut rent in case it is found to be too high. ${ }^{3}$

This renaissance of rent control even in the rigid forms of freezing rents introduced as first generation of controls during the World Wars is surprising given the almost unanimous agreement of economists about the negative effects of rent controls in general and tenancy regulation

\footnotetext{
${ }^{1}$ Senate Bill 608 relating to residential tenancies; creating new provisions; amending ORS 90.100, 90.220, 90.323, 90.427, 90.600, 90.643, 90.675 and 105.124; and declaring an emergency.

${ }^{2}$ Decreto ley $9 / 2019$, de 21 de mayo, de medidas urgentes en materia de contención de rentas en los contratos de arrendamiento de vivienda y de modificación del libro quinto del Código civil de Cataluña en el ámbito de la prenda. This regulation was apparently influenced to a large extent by the so-called rental brake (Mietpreisbremse) introduced in Germany in 2015.

${ }^{3}$ See official explanations of the planned regulations: https://www.stadtentwicklung.berlin.de/wohnen/ wohnraum/mietendeckel/index.shtml. Inspired by Berlin's initiative the leftist government of another German Bundesland Bremen expressed its intention to closely follow the capital city's experience in order to eventually implement similar measures.
} 
in particular on the allocation of housing. Among the negative effects attributed to these market regulations the allegedly negative effect on new construction is probably the most prominent. Arnott (1995, p.99) noted the "widespread agreement that rent control discourages new production." The restrictive housing market governmental regulations aiming to protect tenants from unreasonable rent increases and evictions are thus blamed for depressing construction activities and aggravating housing shortages. It is thought to reduce incentives for investing in new residential construction, especially of rental housing, since governmental restrictions limit rental revenues and the freedom of disposing of the real estate properties. Today's climate of urban housing shortages in many booming European cities lead many economists to regard the removal of rent regulations as stimulus for new housing supply.

This study critically investigates the relationship between restrictive governmental housing regulations - such as rent control, protection from eviction, and housing rationing - and the residential construction. It draws on two novel databases ranging from 1910-2017 for 16 developed countries and from 1980-2017 for 44 developing countries: one contains regulation indices based on manual coding of all major tenancy-related laws in a country, and one on building activity. The regulation data includes data on regulation intensities for the three types of restrictive housing policies with regard to rent control, security of tenancy and rationing of housing units. The indices measure the intensity of regulations and vary between 0 and 1 , the higher values meaning a more active intervention of the government in the market activities and less freedom for the market participants, especially the landlords. The second database contains the annual time series of new residential construction (housing units). In addition, a wide range of control variables are used, which reflect both economic (real GDP per capita, long-term interest rates, mortgage debt) and demographic (population growth, total dependency ratio, marriage rates) factors that are likely to affect building activity.

Our results tend to confirm the economists' view: in normal and post-war periods, in developing and developed countries, rent controls, tenancy-security and rationing regulation have negative effects on new construction activity, but the significance is not as clear-cut as economists would expect. Whereas rationing measures are significant throughout, security of tenancy regulation is mostly insignificant and price regulation is significant for the developed world in normal times only. Increasing the regulation by 1 on a scale from 0 to 1 , decreases 
new construction by 0.06 per 1000 inhabitants. But this evidence also nuances the received view: the negative effect is not as universal as generally expected. It is restricted to a subset of countries and years. Moreover, we find evidence for a non-linearity: the negative effect on construction only becomes active beyond a certain threshold. It is mostly significant for the rigid first-generation absolute rent controls or rent freezing, but not necessarily for the second-generation controls of relative price increases. We suggest that the rather surprising non-universality of the rent-control effect could be explained by the fact that new construction has mostly been excepted from rent control. Moreover, rent controls crowd out rental units in favor of owner-occupied ones which can enjoy ongoing construction despite rent control. Finally, rent control rarely comes without active government housing policies in favor of new construction which can compensate for the loss of private construction. Beyond rent control, the finding highlights that historical circumstances matter for expected effects to realize. In that, rent control appears to be similar to minimum wage, a price freeze used on labor markets.

This paper is structured as follows. Section 2 reviews the literature on the effects of governmental regulations on the residential construction. In section 3 our data are described. Section 4 explains the methodology applied in this study, while section 5 discusses the obtained results. Finally, section 6 draws conclusions.

\section{Determinants of residential construction}

In this section, we briefly review works that investigated the effect of rent regulation on new construction. Moreover we present a list of studies explaining new construction outcomes to assemble necessary control variables for our own estimations below.

Rent regulation is a widely investigated phenomenon (Arnott, 1995), even though crossnational quantitative studies of their effect on new residential construction is less well-covered. The evidence of existing studies which all investigate the recent surge of rent legislation on the two coasts of the United States or in Europe is rather mixed. The best evidence comes from sub-national case studies. The most prominent recent quasi-experimental study of SanFrancisco estimated the effect on rent controls on new construction to amount to a reduction of 15 percent (Diamond et al., 2019). Also studying San Francisco, Asquith (2019) finds a reduction rental housing supply, as landlords sell off apartments in the condo-market or hold 
back supply. A similar phenomenon - a conversion of rental into owner-occupied units - has been found by Fetter 2016 for the US rent controls during World War II.

However, Sims (2007), using microdata from a housing survey conducted in Massachusetts in 1985-1998, finds little effect of rent control on new housing construction. Studying the same de-control moment, Autor et al. (2014) also find a very low effect of de-control on new residential investment. Mense et al. (2018), who investigate a recent strengthening of German rental policy - the rental brake (Mietpreisbremse) - establish that it fostered new construction in the controlled municipalities.

Besides studies of rent control, there has been an interest to predict housing supply and the building cycle, given its importance for the overall business cycle and employment in countries. The literature is, however, rather under-developed and inconclusive (DiPasquale, 1999; Vermeulen and Rouwendal, 2007). Generally, studies explaining new construction (in single or multi-family buildings) or new residential investment (or repair investment) in cities or metropolitan areas find a positive house-price-elasticity that can range between 0 and 6 , depending on the country and on the short- or long-run (Malpezzi and Maclennan, 2001). But prices alone do not suffice to explain variation in construction. Usually, additional factors such as demography (population size, growth and structure), inflation and the time it needs to sell are also found to play a role. In a study of four historical German cities during the pre-WWI urbanization wave, for instance, the number of marriages was found to be nearly the single most-important predictor of new supply (Wellenreuther, 1989b). Surprisingly, construction costs are often found to be insignificant or indeterminate in direction (Caldera and Johansson, 2013). Supply of sufficient land for construction has been found to impact on the supply elasticity in construction (Glaeser et al., 2008a). Mortgage market conditions themselves are hardly mentioned in this literature which is probably due to the fact that many studies use regional US data and urban or regional mortgage data are difficult to come by. In the few cases where interest rates, credit constraints or savings deposits are mentioned (DiPasquale and Wheaton, 1994a; Poterba, 1984), they point in the expected direction: more permissive mortgage conditions and capital injections are a demand stimulus for housing supply. We summarize the more detailed findings of these studies in Table 1 and note that demographic and economic controls such as such as interest rates, building costs, economic growth, marriage rates and population 
rates, housing price stimulation, etc. are among the frequently used control variables.

\section{Data}

In this section, we present the variables and operationalization used in this study. For the sake of convenience, we split them into dependent variable, control variables, and regulation indices. Table 3 reports the sources of data in more detail and presents the descriptive statistics.

\subsection{Housing construction intensity}

Our dependent variable is the housing construction intensity, which is defined as the number of completed dwellings per 1000 persons. Surveying construction requires a certain governmental control of property rights and the construction sector which is not given in many developing nations and therefore restricts the countries we can sensibly include in the study. Construction volume is available as permits, starts and completions, unfortunately with different country coverage. The advantage of housing starts (and permits) as measure is that they are the most sensitive measures to reveal macroeconomic impacts on initiated construction activity. Their obvious shortcoming is that not all housing starts end up in completions and capital formation due to construction-loan problems, bad calculations, or speculation. Completions, in turn, have the disadvantage that they lag behind starts with one or two years. On the positive side, however, they indicate what really has been constructed and their coverage across countries is highest. For these reasons, we opt for completions as the measure for new construction volume. To control for demography right from the start, we divide completions by the current population, which yields a commonly used variable in the range of 2 to 15 completed units per 1000 inhabitants. In cases of missing completion data due to countries' not having surveyed them at all (Belgium) or only at certain points in time (USA), we approximate completions through housing starts and permits. Our rule of approximation is the following: If available, we use the first lag of housing starts multiplied by the median ratio of housing completions and starts in our sample excluding the war and post-war years, namely 0.98. If starts are also not available, we use the first lag of permits again multiplied by the average ratio of housing completions and permits, namely 0.95. This is to make sure that the levels of completions is approximated, as the over-time trends is highly similar. For the available data, both lagged permits and lagged housing starts strongly correlate $(\mathrm{r}=0.98)$. 


\subsection{Control variables}

Based on the literature review we identified the list of variables to be controlled for, mainly the common demographic and economic background variables. Additions to the housing stock are a reaction to demographic needs. We therefore control for population growth to account for rising demand. As a more refined measure, we also control for marriage rates per population because they indicate the formation of new households. Family formation requires the extension of living space, whereas older household cut back leaving space at higher age. We therefore also include dependency ratio by interpolating the age composition of the population surveyed at census points. ${ }^{4}$

On the economic side, we control for GDP per capita as higher income levels allow for more construction to take place. The business cycle is also known for its strong correlation with the building cycle (Leamer, 2007). Most new construction is not financed out of equity, which is why capital markets play a crucial role. We, therefore, include long-term interest rates that govern mortgage lending. Moreover, we include the growth of mortgage lending: in normal times, more mortgage supply should lead to new construction, but we also include its quadratic term, as too high levels of mortgage indebtedness has been found to just drive up prices and to not extend supply further. New construction depends on the relative attractiveness to build, we, therefore, include the relative rate of return computed as a difference between housing rental returns and stock market returns in the estimation.

\subsection{Regulation indices}

This study focuses on the effects of governmental regulations. Therefore, we need measures of intensity of such regulations. For this purpose, we use the restrictive rental market regulations indices elaborated by Kholodilin (2018) and Weber (2017). They cover three types of regulations: rent control, tenure security, and housing rationing. Rent control index measures the intensity restrictions imposed on the level of rent and its rate of increase. Economists distinguish between the first and second-generation rent control (Arnott, 1995). The first generation implies a rent freeze, when rents are fixed at some level, while under the second-generation rent

\footnotetext{
${ }^{4}$ Marriage rates and age composition are interpolated using an $\mathbf{R}$-package stinepack based on Stineman (1980).
} 
control, starting rent is generally set at the market level, but its growth rate is anchored to some measure of living cost. Here, we use two regulation indices, $R C_{-} 1$ and $R C_{-} 2$, for the first- and second-generation rent control, respectively. The tenure security index reflects the degree of protection of tenants from evictions by landlords. The main instruments of protection are 1) eviction protection during term or period; 2) eviction protection at the end of term or period; 3) imposition of minimum duration of rental contracts; and 4) prohibition of short-term (less than one year) tenancies. The housing rationing index measures the intensity of redistribution of the existing housing stock. All three indices can vary between 0 and 1: the higher the index the more intense the regulation. The indices are constructed based on a thorough analysis of the corresponding legal acts. Table 2 lists the countries for which regulation indices are constructed.

\section{Econometric methodology}

In this section, we describe the methodology used to estimate the impact of restrictive housing regulations upon construction intensity. The availability of longitudinal data suggests the use of a panel data model. Given the strong persistence of construction intensity and in order to remove serial correlation and potential non-stationarity, we compute the dependent variable as the first difference of the log of construction intensity.

$$
y_{i t}=\beta^{\prime} x_{i t}+\gamma^{\prime} z_{i, t-2}+\eta_{i}+\theta_{t}+v_{i t}
$$

where $y_{i t}$ is the first difference of the construction intensity in country $i$ in the year $t$; $x_{i t}$ is the vector of control variables; $z_{i t}$ is the vector of regulation indices; $\eta_{i}$ is the country fixed effects; $\theta_{t}$ is the time fixed effects; $v_{i t}$ is the random disturbance; and $\beta$ is the vector of coefficients.

We transform the explanatory variables that are non-stationary (population, mortgages, GDP per capita) into growth rates or first differences which also transforms these stock-variables into flows, better apt to explain the flow of new constructions. We use the second lag of the regulation indices in order to capture the fact that housing construction takes time. Thus, changes in regulations affect first the willingness of investors to apply for permits. Only after the permits are obtained the construction can begin. For the control variables we use their first 
lags. Given that we work with annual data, one lag should be sufficient.

\section{Results}

We first describe how construction and tenancy regulation developed across time and regions to then present the multivariate results.

\subsection{Descriptive findings}

Figure 1 depicts the evolution of the three regulation indices between 1910 and 2017. All curves show a two-hump structure: regulation set in with World War I (WWI) as consumer socialism for the home front of soldiers' families, was then reversed during the interwar years only to spike again during World War II (WWII). But whereas rationing was almost completely reversed afterwards, tenancy security was largely maintained throughout all jurisdictions on average. Rent regulation itself lost in intensity everywhere: the strong first-generation freezes of absolute rent levels softened into second-generation regulation of rent increases. While this is a broad common stories across jurisdictions, there are notable country-group differences: socialist countries are obviously among the most regulated even after wars, countries of English law tradition least so. The remaining mostly European countries show a more loosely regulated German-law tradition in contrast to more regulated Scandinavian and French law tradition.

Figure 2 adds the long-run construction cycle to the picture. Socialist countries excepted, there is a rough countercyclical movement of construction and rent regulation over the 20th century: rent regulation surges in war times when construction is low and is fades out with the building cycle taking off. Towards the end of the reporting period, the negative correlation is less evident as building cycles can occur even at a constant rent level.

\subsection{Multivariate estimations}

In what follows, we estimate five different models, depending on the combination of rental regulation indices and control variables included. We estimate these five models four times in four different tables, making use of the different subsamples. We first start with the global estimate of all countries and all years and, secondly, take all countries but excluding the war and post-war periods before 1960. Figure 3 shows 60 countries for which the regressions in Tables 4 and 5 are estimated. The unbalanced number of observations varies from 30 for Slovakia to 87 
for 19 developed countries. For these global samples, we need to do with less control variables for reasons of availability.

The third and fourth samples narrows in on just the developed countries again for the whole time period and for the war-unaffected post-1960 period only. In Figure 4, the data availability for the 16 developed countries is shown. For these countries a much wider set of control variables is available, which are used to estimate regressions reported in Tables 6 and 7.

Tables 4 and 5 report estimation results for a wide panel of countries for the whole sample and war-unaffected subsample, respectively, because war- and post-war-times are arguably very unrepresentative times for housing policies and rent policies in particular. Rental regulation effects are somewhat stronger for the war-unaffected period. Three regulation indices are statistically significant: housing rationing and, for the war-unaffected subsample, the general rent regulation which is almost completely due to the remaining hard first-generation price controls. All affect the intensity of residential construction negatively. Thus, stricter regulations, limiting the freedom of landlords to set prices and to evict tenants, diminish the incentives to build new housing. During the whole sample, out of the economic control variables, growth of real per-capita GDP is statistically significant. It exerts a strong positive effect on the construction intensity, which corroborates economic theory and common sense. Indeed, rising incomes increase demand for housing and, thus, stimulate construction. For the war-unaffected subsample, marriage rates have a positive statistically significant effect.

Table 6 zooms in on the developed countries only. For the complete time period, all regulation indices display a negative coefficient, but with low significance levels. Here it is the marriage rates and capital markets (interest rates and mortgages) which are significantly associated with new production of housing. While lower interest rates and more mortgages generally lead to increases of new construction, an overextension of mortgages even depresses new construction (negative quadratic term). The addition of demographic and particularly economic variables normally associated with the building cycle takes away the significance of regulation indices.

Much of this is however driven by the war-time effects as the war-unaffected subsample results in Table 7 shows: post-1960, all rent regulation indices, including regulation of tenancy security, are negatively associated with construction and significantly so. The one exception is rent price regulation when its quadratic term is added. The effects of rent control on the 
intensity of residential construction are shown for four different subsamples (all vs. developed, whole period vs. post-1960 period) in Figure 5. The linear effects are the smallest for the models estimated over the whole period: the largest decline of the growth rate of construction intensity is obtained for the maximum rent control intensity (equal to 1) and is between $-1.3 \%$ for all and $-1.6 \%$ for developed economies. For the post-1960 period, the effects are much larger, varying from the largest decline of about $-6 \%$ for all countries to almost $-8 \%$ for developed ones. Assume that in the initial situation (period $t$ ) there is no rent control and that construction intensity is 10 dwellings per 1000 inhabitants. If next year $(t+1)$ the strictest rent control policy is introduced, in $t+3$ the construction intensity would fall to $9.84-9.87$ dwellings per 1000 persons for the whole period and to 9.2-9.4 dwellings per 1000 persons for the post-1960 period. In a country with 100 million inhabitants, it would correspond to a reduction of residential construction by 13,000-16,000 and 60,000-80,000 dwellings, respectively. Non-linear effects are evident in three cases out of four; only in the model estimated for the whole sample, there is no visible difference between the linear and quadratic effects. In the models estimated for the whole period, the largest decline in the construction intensity is observed at the rent control intensity of 0.6; the consequent invigoration of rent control leads to diminishing negative effects. The non-linear effects can in part be explained by an extensive government support of construction, which often accompanies very strict rent control. The government observes that strong rent controls lead to a dramatic fall in construction intensity and is forced to undertake measures in order to encourage building activities. Since we do not have reliable variables capturing such policies, this effect is captured by the non-linear models estimated for the whole period. Taking our previous example, the introduction of rent control with intensity 0.6 in $t+1$, would lead in period $t+3$ to a decline of construction intensity to about 9.72-9.74 dwellings per 1000 inhabitants, corresponding to a fall of total construction by $26,000-28,000$ units. In the case of developed countries after 1959, the increase of rent control intensity from 0 to 0.3 does not really affect the residential construction intensity. It is only beyond this level that negative the impact is put in force. Overall, the magnitude of rent control effects in these models is sizable, but perhaps below the negative impact usually expected. 


\section{Discussion and conclusion}

The overall finding points to a negative impact of rent regulation on new residential construction: throughout different samples and specifications, the regulation coefficients are negative, albeit with changing levels of significance. The finding is most persistent for rationing and first-generation rent-control and most pronounced for the war-unaffected period which reaches up to the current day. But for developed countries, even higher levels of security of tenure can depress new construction.

This overall finding, however, needs to be nuanced. Given the near unanimous position of economists on the effect under study, our study contains some surprising elements: first, both models covering the whole time period do not find any significant rent-control effect other than for the war-related first-generation controls and rationing. One explanation could be that lower rent law levels correspond to the more flexible first-generation rent control, while higher ones correspond to the much more restrictive first-generation rent control. This is in line with the previous research (Mense et al., 2018). Second, there is (weak) evidence for a non-linearity of the rent-control effect: beyond a certain threshold, rent control loses its bite on new construction, probably because no further crowding-out takes place and perhaps even a crowding-in through state construction. Finally, one could argue that the magnitude of the examined effects is not particularly high in general.

What could explain the deviance from the usually expected result? One obvious explanation is that rent control laws often exempt new construction from regulations. The purpose of such exceptions is to guarantee that the incentives for building new houses are not diminished. Thus, the rents for newly built dwellings are not controlled and so the investors can earn decent profits on it. But investors might still shy away from further investment in rental stock, as they might expect a general deterioration of investment climate and a slippery slope towards even more state intervention.

A second explanation can draw on the fact that rent regulation crowds out rental dwellings in favor of owner-occupied ones (Fetter, 2016). A potential reduction of completions of rental dwellings can thus be more than offset by the increase in the completion numbers of the owneroccupied housing. This is all the more probable, given the finding of some researchers that the homeowner dominated societies are more prone to the speculative house price dynamics. The 
homeowners or would be owners seeing the house price increases and expecting them to go on further are eager to participate in the overall speculative movement hoping to obtain capital gains. Thus, more housing is built in such economies than in the tenant dominated ones, where most people are rather unwilling to see the house prices increase, since this often goes hand in hand with the rent increases. It should be noted also that the switch from a tenant dominance to a homeowner dominance can be a result of too strict rental regulations. In principle, one would need to replace our current dependent variable of all new constructions by the new rental constructions, but the future use of a housing unit is not necessarily known, let alone surveyed, at the point of its construction.

A final explanation for why rent regulation is not universally damaging new construction resides in the fact that in many historical cases the restrictive rental measures are accompanied by housing policies seeking to foster the building activities through social housing or the stimulation of more private housing construction. This has especially been the case after major housing supply shocks caused by wars or natural catastrophes. The inevitable rent increases are fought against using rent control and the resulting unwillingness to build by private investors makes the government step in and to either replace the private building initiative or stimulate it artificially. This could also explain why the global sample results showed less significant results as they included the period of strongest state intervention in housing markets.

Rent control measures of even the hard first-generation rent freezes are currently debated and passed in European countries and beyond. Often introduced with good intentions as social policy in favor of tenants, our results suggest that economists have a point when warning about its unintended consequences of depressing new construction. Rent controls help sitting tenants in the short-run but contribute to future housing shortages for new tenants in the longer-run. This long-run result can partially be offset by additional state policies stimulating housing construction, but under rent control, the efforts to spur residential construction have to be much larger than in its absence. This undermines the frequently used argument that rent control is an interim measure employed in order to combat the rent increasing, while awaiting for the construction to gain momentum. Therefore, if one wants to overcome the housing shortage as soon as possible, it is better to abstain from restricting rents, especially from using the first-generation rent control. 


\section{Literature}

Arnott, R. (1995). Time for revisionism on rent control? Journal of Economic Perspectives 9(1), 99-120.

Asquith, B. J. (2019). Housing supply dynamics under rent control: What can evictions tell us? AEA Papers and Proceedings 109, 393-96.

Autor, D. H., C. J. Palmer, and P. A. Pathak (2014). Housing market spillovers: Evidence from the end of rent control in Cambridge, Massachusetts. Journal of Political Economy 122(3), $661-717$.

Caldera, A. and A. Johansson (2013). The price responsiveness of housing supply in OECD countries. Journal of Housing Economics 22(3), 231-249.

Diamond, R., T. McQuade, and F. Qian (2019). The effects of rent control expansion on tenants, landlords, and inequality: Evidence from San Francisco. American Economic Review 109 (9), $3365-94$.

DiPasquale, D. (1999). Why don’t we know more about housing supply? The Journal of Real Estate Finance and Economics 18(1), 9-23.

DiPasquale, D. and W. C. Wheaton (1994a). Housing market dynamics and the future of housing prices. Journal of Urban Economics 35(1), 1-27.

DiPasquale, D. and W. C. Wheaton (1994b). Housing market dynamics and the future of housing prices. Journal of Urban Economics 35(1), 1-27.

Fetter, D. K. (2016). The home front: Rent control and the rapid wartime increase in home ownership. The Journal of Economic History 76(4), 1001-1043.

Follain, J. R., D. R. Leavens, and O. T. Velz (1993). Identifying the effects of tax reform on multifamily rental housing. Journal of Urban Economics 34(2), 275-298.

Glaeser, E. L., J. Gyourko, and A. Saiz (2008a). Housing supply and housing bubbles. Journal of Urban Economics 64(2), 198-217. 
Glaeser, E. L., J. Gyourko, and A. Saiz (2008b). Housing supply and housing bubbles. Journal of Urban Economics 64(2), 198-217.

Kholodilin, K. A. (2018). Measuring stick-style housing policies: A multi-country longitudinal database of governmental regulations. DIW Berlin Discussion Paper 1727.

Kohl, S. (2020). Too much mortgage debt? The effect of housing financialization on housing supply and residential capital formation. Socio-Economic Review.

Leamer, E. E. (2007). Housing is the business cycle. National Bureau of Economic Research.

Malpezzi, S. and D. Maclennan (2001). The long-run price elasticity of supply of new residential construction in the United States and the United Kingdom. Journal of Housing Economics 10(3), 278-306.

Mense, A., C. Michelsen, and K. Kholodilin (2018). Empirics on the causal effects of rent control in Germany. Beiträge zur Jahrestagung des Vereins für Socialpolitik 2018: Digitale Wirtschaft - Session: Inequality III, No. E04-V3.

Mitchell, B. (2013). International historical statistics, 1750-2010. Palgrave/Macmillan.

Murray, M. P. (1999). Subsidized and unsubsidized housing stocks 1935 to 1987: Crowding out and cointegration. The Journal of Real Estate Finance and Economics 18(1), 107-124.

Poterba, J. M. (1984). Tax subsidies to owner-occupied housing: An asset-market approach. The Quarterly Journal of Economics 99(4), 729-752.

Sims, D. P. (2007). Out of control: What can we learn from the end of Massachusetts rent control? Journal of Urban Economics 61(1), 129-151.

Stineman, R. W. (1980). A consistently well-behaved method of interpolation. Creative Computing 6, 54-57.

Topel, R. and S. Rosen (1988). Housing investment in the United States. Journal of Political Economy 96(4), 718-740. 
Vermeulen, W. and J. Rouwendal (2007). Housing supply and land use regulation in the Netherlands. Tinbergen Institute Discussion Paper.

Weber, J. P. (2017). The regulation of private tenancies - A multi-country analysis. Dissertation.

Wellenreuther, T. (1989a). Wohnungsbau und Industrialisierung. Eine ökonometrische Untersuchung am Beispiel Deutschlands von 1850 bis 1913. Bergisch Gladbach/Köln: J. Eul.

Wellenreuther, T. (1989b). Wohnungsbauinvestitionen und dere Konjunktur im deutschen Industrialisierungsprozeß 1850-1913: eine ökonometrische Untersuchung. Ph. D. thesis, Eul. 
Figures and tables

Table 1: Literature explaining construction activity

\begin{tabular}{|c|c|c|c|}
\hline Study & Data range & Method & Main finding \\
\hline $\begin{array}{l}\text { Caldera and } \\
\text { Johansson } \\
\text { (2013) }\end{array}$ & $\begin{array}{l}21 \text { OECD countries, } \\
1980 \mathrm{~s}-\text { mid-2000s, } \\
\text { quarterly }\end{array}$ & $\begin{array}{l}\text { Error correction } \\
\text { model }\end{array}$ & $\begin{array}{l}\text { Long-run: Lagged prices }(+) \text {, percent aged } \\
25-44 \text { years }(+) \text {, construction costs } \\
/+) \text {, but country specificities. Short-run: } \\
\text { lagged prices }(+)\end{array}$ \\
\hline $\begin{array}{l}\text { Glaeser et al. } \\
(2008 \mathrm{~b})\end{array}$ & $\begin{array}{l}79 \text { US metropolitan ar- } \\
\text { eas, } 1982-2007\end{array}$ & $\begin{array}{l}\text { Time series analy- } \\
\text { sis }\end{array}$ & House prices $(+)$, land accessibility $(+)$ \\
\hline $\begin{array}{l}\text { Follain et al. } \\
(1993)\end{array}$ & $\begin{array}{l}4 \text { metropolitan areas } \\
\text { (Atlanta, Chicago, Dal- } \\
\text { las, Oakland), 1977- } \\
\text { 1990, quarterly data }\end{array}$ & $\begin{array}{l}\text { OLS on panel } \\
\text { data }\end{array}$ & $\begin{array}{l}\text { Rents, the capitalization rate, replacement } \\
\text { cost per unit of rental housing }\end{array}$ \\
\hline $\begin{array}{l}\text { Wellenreuther } \\
(1989 a)\end{array}$ & $\begin{array}{l}4 \text { German cities, } 1860- \\
1913\end{array}$ & $\begin{array}{l}\text { Time series analy- } \\
\text { sis }\end{array}$ & Marriages $(+)$ \\
\hline $\begin{array}{l}\text { Murray } \\
\text { (1999) }\end{array}$ & USA, 1935-1987 & $\begin{array}{l}\text { Vector error cor- } \\
\text { rection model }\end{array}$ & $\begin{array}{l}\text { Positive effect of public housing (but not } \\
\text { moderate-income housing) on supply, be- } \\
\text { cause no crowding-out of private offer }\end{array}$ \\
\hline $\begin{array}{l}\text { DiPasquale } \\
\text { and Wheaton } \\
\text { (1994b) }\end{array}$ & $\begin{array}{l}\text { USA, 1960-1990, single- } \\
\text { family starts }\end{array}$ & $\begin{array}{l}\text { Time series analy- } \\
\text { sis }\end{array}$ & $\begin{array}{l}\text { Prices }(+) \text {, land costs }(0) \text {, short-term in- } \\
\text { terest rates }(-) \text {, construction cost }(0) \text {, } \\
\text { lagged housing stock, months on the mar- } \\
\text { ket }(+)\end{array}$ \\
\hline $\begin{array}{l}\text { Topel and } \\
\text { Rosen (1988) }\end{array}$ & USA, 1963-1984 & $\begin{array}{l}\text { Time series analy- } \\
\text { sis }\end{array}$ & $\begin{array}{l}\text { High long-run and lower short run price } \\
\text { elasticity }(+), \text { construction cost }(0) \text {, } \\
\text { months on the market }(+)\end{array}$ \\
\hline $\begin{array}{l}\text { Poterba } \\
(1984)\end{array}$ & USA, 1974-1982 & $\begin{array}{l}\text { Time series analy- } \\
\text { sis }\end{array}$ & $\begin{array}{l}\text { Price }(+) \text {, real construction wages }(0) \text {, } \\
\text { savings deposits }(+) \text {, non-residential con- } \\
\text { struction prices }(-)\end{array}$ \\
\hline
\end{tabular}


Table 2: List of countries, for which regulation indices are constructed

\begin{tabular}{|c|c|c|c|}
\hline Continent & Countries & $\begin{array}{l}\text { Sample } \\
\text { size }\end{array}$ & $\begin{array}{l}\text { Total } \\
\text { coun- } \\
\text { tries } \\
\text { (states) }\end{array}$ \\
\hline Africa & $\begin{array}{l}\text { Algeria, Angola, Benin, Madagascar, Mali, Morocco, Niger, } \\
\text { Senegal, South Africa, Togo, Tunisia }\end{array}$ & 11 & 60 \\
\hline Asia & $\begin{array}{l}\text { Armenia, Azerbaijan, Cyprus, Hong Kong, India (Delhi, } \\
\text { Maharashtra, Punjab, Uttar Pradesh, West Bengal), Israel, } \\
\text { Macao, Myanmar, Pakistan (Punjab), Philippines, Singa- } \\
\text { pore, Turkey }\end{array}$ & 16 & 51 \\
\hline Europe & $\begin{array}{l}\text { Andorra, Austria, Belarus, Belgium, Bulgaria, Czech Re- } \\
\text { public, Denmark, Estonia, Finland, France, GDR, Germany, } \\
\text { Greece, Iceland, Ireland, Italy, Latvia, Liechtenstein, Lithua- } \\
\text { nia, Luxembourg, Malta, Monaco, Netherlands, Norway, } \\
\text { Poland, Portugal, Romania, Russia, San Marino, Slovakia, } \\
\text { Spain, Sweden, Switzerland, UK, Ukraine }\end{array}$ & 35 & 53 \\
\hline LAC & $\begin{array}{l}\text { Argentina, Bolivia, Brazil, Chile, Colombia, Cuba, Domini- } \\
\text { can Republic, Haiti, Jamaica, Mexico (Distrito Federal, Ve- } \\
\text { racruz), Nicaragua, Panama, Peru, Salvador, Trinidad and } \\
\text { Tobago, Uruguay }\end{array}$ & 17 & 52 \\
\hline $\begin{array}{l}\text { North Amer- } \\
\text { ica }\end{array}$ & Canada (Alberta, Ontario, Quebec), USA & 4 & $5(60)$ \\
\hline Oceania & Australia, French Polynesia, New Zealand & 3 & 29 \\
\hline \multicolumn{2}{|l|}{ World } & 86 & 250 \\
\hline
\end{tabular}


Table 3: Description of variables used in the analysis

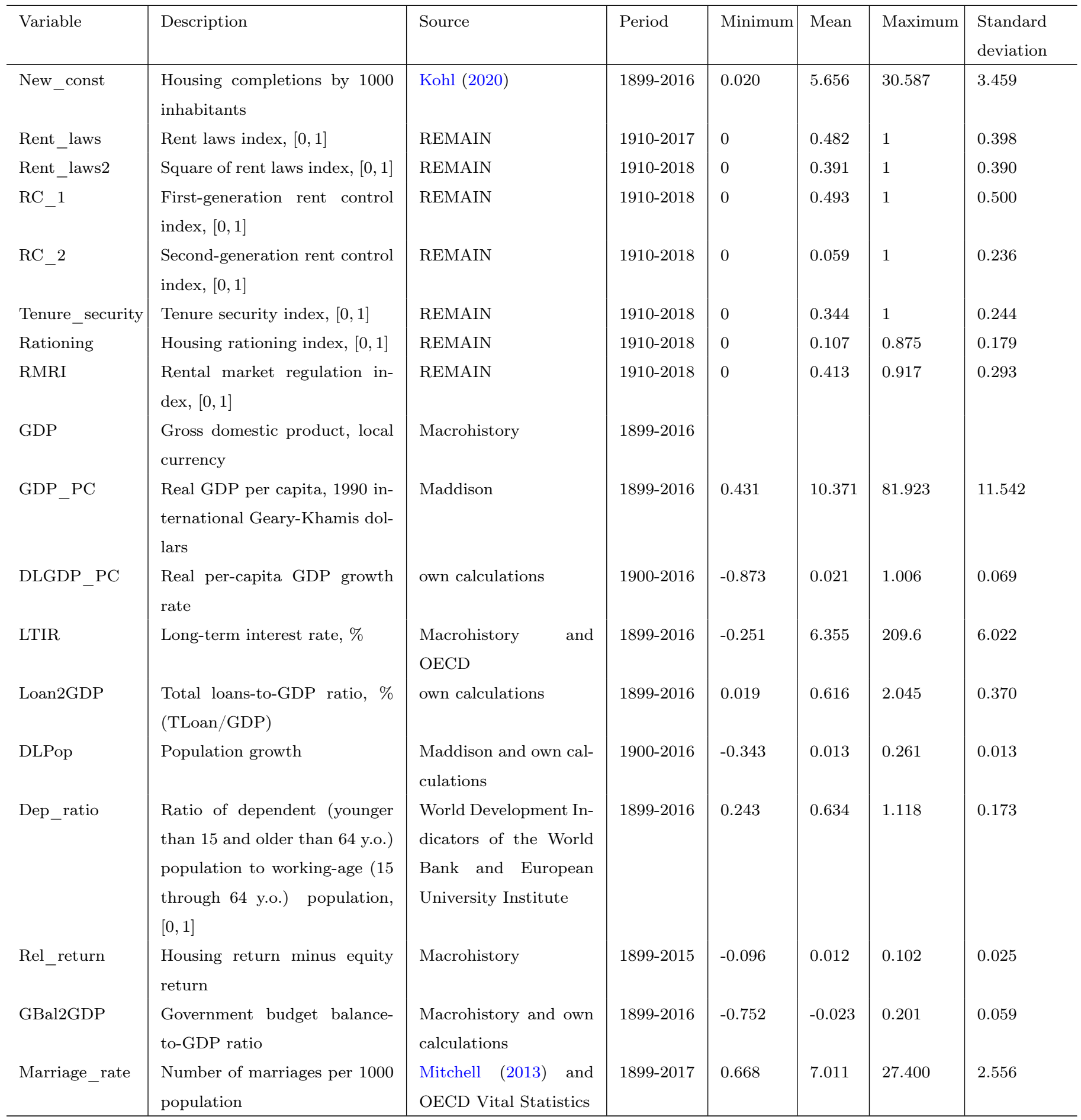

Note: BIS = Bank for International Settlements (https://www.bis.org/statistics/pp_detailed.htm); Federal Reserve Bank of Dallas (https://www.dallasfed. org/institute/houseprice\#tab2); Macrohistory = Jordà-Schularick-Taylor Macrohistory Database (http://www.macrohistory.net/data/); Maddison = Maddison Historical Statistics (https://www.rug.nl/ggdc/historicaldevelopment/maddison/); OECD = Organization for Economic Cooperation and Development Housing prices data (https://data.oecd.org/price/housing-prices.htm); REMAIN = Rental Market Regulation Index database (https://www.remain-data. org/). 
Table 4: Estimation results of panel data model: all countries, whole period

\begin{tabular}{|c|c|c|c|c|}
\hline \multicolumn{5}{|c|}{ Dependent variable: growth rate of construction intensity } \\
\hline & Model 1 & Model 2 & Model 3 & Model 4 \\
\hline \multirow[t]{2}{*}{ Rent_laws_lag2 } & -0.013 & & & -0.088 \\
\hline & $(0.026)$ & & & $(0.089)$ \\
\hline \multirow[t]{2}{*}{ Rent_laws2_lag2 } & & & & 0.075 \\
\hline & & & & $(0.100)$ \\
\hline \multirow[t]{2}{*}{ RC1_lag2 } & & & $-0.033^{*}$ & \\
\hline & & & $(0.015)$ & \\
\hline \multirow[t]{2}{*}{$\mathrm{RC} 2$ _lag2 } & & & -0.013 & \\
\hline & & & $(0.022)$ & \\
\hline \multirow[t]{2}{*}{ Tenure_security_lag2 } & -0.022 & & -0.013 & -0.014 \\
\hline & $(0.063)$ & & $(0.069)$ & $(0.057)$ \\
\hline \multirow[t]{2}{*}{ Rationing_lag2 } & $-0.147^{* *}$ & $-0.146^{* *}$ & $-0.133^{* *}$ & $-0.156^{* *}$ \\
\hline & $(0.050)$ & $(0.047)$ & $(0.046)$ & $(0.057)$ \\
\hline \multirow[t]{2}{*}{ RMRI_lag2 } & & -0.031 & & \\
\hline & & $(0.037)$ & & \\
\hline \multirow[t]{2}{*}{ Dep_ratio_lag1 } & -0.064 & -0.066 & -0.057 & -0.061 \\
\hline & $(0.108)$ & $(0.116)$ & $(0.117)$ & $(0.109)$ \\
\hline \multirow[t]{2}{*}{ DLGDP_PC_lag1 } & $0.472^{* * *}$ & $0.472^{* * *}$ & $0.470^{* * *}$ & $0.475^{* * *}$ \\
\hline & $(0.137)$ & $(0.137)$ & $(0.138)$ & $(0.136)$ \\
\hline \multirow[t]{2}{*}{ DLpop_lag1 } & 0.781 & 0.770 & 0.793 & 0.736 \\
\hline & $(1.163)$ & $(1.106)$ & $(1.132)$ & $(1.149)$ \\
\hline \multirow[t]{2}{*}{ Marriage_rate_interp } & 0.015 & 0.015 & 0.015 & 0.015 \\
\hline & $(0.010)$ & $(0.010)$ & $(0.010)$ & $(0.010)$ \\
\hline $\mathrm{R}^{2}$ & 0.027 & 0.027 & 0.029 & 0.028 \\
\hline Num. obs. & 2225 & 2225 & 2225 & 2225 \\
\hline
\end{tabular}

${ }^{* * *} p<0.001,{ }^{* *} p<0.01,{ }^{*} p<0.05$ 
Table 5: Estimation results of panel data model: all countries, 1960-2017

\begin{tabular}{|c|c|c|c|c|}
\hline \multicolumn{5}{|c|}{ Dependent variable: growth rate of construction intensity } \\
\hline & Model 1 & Model 2 & Model 3 & Model 4 \\
\hline \multirow[t]{2}{*}{ Rent_laws_lag2 } & $-0.057^{* *}$ & & & -0.055 \\
\hline & $(0.018)$ & & & $(0.070)$ \\
\hline \multirow[t]{2}{*}{ Rent_laws2_lag2 } & & & & -0.003 \\
\hline & & & & $(0.071)$ \\
\hline \multirow[t]{2}{*}{$\mathrm{RC} 1$ lag2 } & & & $-0.049^{* * *}$ & \\
\hline & & & $(0.013)$ & \\
\hline \multirow[t]{2}{*}{$\mathrm{RC} 2$ _lag2 } & & & -0.030 & \\
\hline & & & $(0.017)$ & \\
\hline \multirow[t]{2}{*}{ Tenure_security_lag2 } & -0.003 & & 0.005 & -0.003 \\
\hline & $(0.041)$ & & $(0.045)$ & $(0.041)$ \\
\hline \multirow[t]{2}{*}{ Rationing_lag2 } & $-0.142^{* * *}$ & $-0.149^{* * *}$ & $-0.145^{* * *}$ & $-0.141^{* * *}$ \\
\hline & $(0.035)$ & $(0.034)$ & $(0.034)$ & $(0.035)$ \\
\hline \multirow[t]{2}{*}{ RMRI_lag2 } & & $-0.080^{* *}$ & & \\
\hline & & $(0.031)$ & & \\
\hline \multirow[t]{2}{*}{ Dep_ratio_lag1 } & 0.037 & 0.051 & 0.065 & 0.037 \\
\hline & $(0.100)$ & $(0.105)$ & $(0.098)$ & $(0.104)$ \\
\hline \multirow[t]{2}{*}{ DLGDP_PC_lag1 } & $0.416^{* * *}$ & $0.415^{* * *}$ & $0.415^{* * *}$ & $0.416^{* * *}$ \\
\hline & $(0.122)$ & $(0.122)$ & $(0.121)$ & $(0.122)$ \\
\hline \multirow[t]{2}{*}{ DLpop_lag1 } & 1.040 & 1.091 & 1.021 & 1.041 \\
\hline & $(1.252)$ & $(1.248)$ & $(1.250)$ & $(1.265)$ \\
\hline \multirow[t]{2}{*}{ Marriage_rate_interp } & $0.023^{* * *}$ & $0.023^{* * *}$ & $0.025^{* * *}$ & $0.023^{* * *}$ \\
\hline & $(0.005)$ & $(0.005)$ & $(0.005)$ & $(0.005)$ \\
\hline $\mathrm{R}^{2}$ & 0.040 & 0.039 & 0.042 & 0.040 \\
\hline Num. obs. & 1870 & 1870 & 1870 & 1870 \\
\hline
\end{tabular}

${ }^{* * *} p<0.001,{ }^{* *} p<0.01,{ }^{*} p<0.05$ 
Table 6: Estimation results of panel data model: developed countries, whole period

\begin{tabular}{|c|c|c|c|c|}
\hline \multicolumn{5}{|c|}{ Dependent variable: growth rate of construction intensity } \\
\hline & Model 1 & Model 2 & Model 3 & Model 4 \\
\hline Rent_laws_lag2 & $\begin{array}{l}-0.026 \\
(0.036)\end{array}$ & & & $\begin{array}{l}-0.160 \\
(0.111)\end{array}$ \\
\hline Rent_laws2_lag2 & & & & $\begin{array}{c}0.127 \\
(0.110)\end{array}$ \\
\hline RC1_lag2 & & & $\begin{array}{l}-0.031 \\
(0.020)\end{array}$ & \\
\hline $\mathrm{RC} 2$ _lag2 & & & $\begin{array}{c}0.013 \\
(0.027)\end{array}$ & \\
\hline Tenure_security_lag2 & $\begin{array}{c}-0.083^{*} \\
(0.041)\end{array}$ & & $\begin{array}{c}-0.102^{*} \\
(0.051)\end{array}$ & $\begin{array}{l}-0.073 \\
(0.039)\end{array}$ \\
\hline Rationing_lag2 & $\begin{array}{l}-0.081 \\
(0.095)\end{array}$ & $\begin{array}{l}-0.082 \\
(0.096)\end{array}$ & $\begin{array}{l}-0.071 \\
(0.096)\end{array}$ & $\begin{array}{l}-0.087 \\
(0.099)\end{array}$ \\
\hline RMRI_lag2 & & $\begin{array}{c}-0.094 \\
(0.063)\end{array}$ & & \\
\hline DLGDP_PC_lag1 & $\begin{array}{c}0.252 \\
(0.179)\end{array}$ & $\begin{array}{c}0.256 \\
(0.179)\end{array}$ & $\begin{array}{c}0.260 \\
(0.181)\end{array}$ & $\begin{array}{c}0.256 \\
(0.177)\end{array}$ \\
\hline LTIR_lag1 & $\begin{array}{c}-0.003^{*} \\
(0.001)\end{array}$ & $\begin{array}{c}-0.003^{*} \\
(0.001)\end{array}$ & $\begin{array}{l}-0.002 \\
(0.001)\end{array}$ & $\begin{array}{l}-0.003 \\
(0.002)\end{array}$ \\
\hline Rel_return_lag1 & $\begin{array}{l}-0.045 \\
(0.222)\end{array}$ & $\begin{array}{c}0.007 \\
(0.225)\end{array}$ & $\begin{array}{c}0.014 \\
(0.232)\end{array}$ & $\begin{array}{l}-0.004 \\
(0.227)\end{array}$ \\
\hline DLoan2GDP_lag1 & $\begin{array}{c}0.177 \\
(0.176)\end{array}$ & $\begin{array}{c}0.189 \\
(0.179)\end{array}$ & $\begin{array}{c}0.185 \\
(0.177)\end{array}$ & $\begin{array}{c}0.195 \\
(0.180)\end{array}$ \\
\hline DLoan2GDP2_lag1 & $\begin{array}{c}-5.032^{* * *} \\
(1.079)\end{array}$ & $\begin{array}{c}-5.142^{* * *} \\
(1.029)\end{array}$ & $\begin{array}{c}-5.068^{* * *} \\
(1.056)\end{array}$ & $\begin{array}{c}-5.140^{* * *} \\
(1.088)\end{array}$ \\
\hline GBal2GDP_lag1 & $\begin{array}{c}0.015 \\
(0.191)\end{array}$ & $\begin{array}{l}-0.013 \\
(0.179)\end{array}$ & $\begin{array}{c}0.030 \\
(0.190)\end{array}$ & $\begin{array}{l}-0.001 \\
(0.197)\end{array}$ \\
\hline DLpop_lag1 & $\begin{array}{c}1.874 \\
(1.637)\end{array}$ & $\begin{array}{c}1.593 \\
(1.634)\end{array}$ & $\begin{array}{l}1.816 \\
(1.701)\end{array}$ & $\begin{array}{c}1.792 \\
(1.667)\end{array}$ \\
\hline Dep_ratio_lag1 & $\begin{array}{l}-0.275 \\
(0.196)\end{array}$ & $\begin{array}{l}-0.292 \\
(0.212)\end{array}$ & $\begin{array}{l}-0.314 \\
(0.203)\end{array}$ & $\begin{array}{l}-0.279 \\
(0.195)\end{array}$ \\
\hline Marriage_rate_interp_lag1 & $\begin{array}{l}0.027^{*} \\
(0.011)\end{array}$ & $\begin{array}{l}0.028^{*} \\
(0.011)\end{array}$ & $\begin{array}{l}0.028^{*} \\
(0.011)\end{array}$ & $\begin{array}{l}0.027^{*} \\
(0.011)\end{array}$ \\
\hline $\mathrm{R}^{2}$ & 0.054 & 0.052 & 0.057 & 0.055 \\
\hline Num. obs. & 1005 & 1005 & 1005 & 1005 \\
\hline
\end{tabular}


Table 7: Estimation results of panel data model: developed countries, 1960-2017

\begin{tabular}{|c|c|c|c|c|}
\hline \multicolumn{5}{|c|}{ Dependent variable: growth rate of construction intensity } \\
\hline & Model 1 & Model 2 & Model 3 & Model 4 \\
\hline Rent_laws_lag2 & $\begin{array}{c}-0.085^{* *} \\
(0.027)\end{array}$ & & & $\begin{array}{l}-0.013 \\
(0.104)\end{array}$ \\
\hline Rent_laws2_lag2 & & & & $\begin{array}{c}-0.069 \\
(0.100)\end{array}$ \\
\hline RC1_lag2 & & & $\begin{array}{c}-0.043^{*} \\
(0.019)\end{array}$ & \\
\hline RC2_lag2 & & & $\begin{array}{c}0.003 \\
(0.025)\end{array}$ & \\
\hline Tenure_security_lag2 & $\begin{array}{l}-0.069 \\
(0.036)\end{array}$ & & $\begin{array}{l}-0.087 \\
(0.046)\end{array}$ & $\begin{array}{l}-0.072 \\
(0.038)\end{array}$ \\
\hline Rationing_lag2 & $\begin{array}{c}-0.221^{* * *} \\
(0.056)\end{array}$ & $\begin{array}{c}-0.221^{* * *} \\
(0.054)\end{array}$ & $\begin{array}{c}-0.231^{* * *} \\
(0.061)\end{array}$ & $\begin{array}{c}-0.224^{* * *} \\
(0.055)\end{array}$ \\
\hline RMRI_lag2 & & $\begin{array}{c}-0.157^{* *} \\
(0.050)\end{array}$ & & \\
\hline DLGDP_PC_lag1 & $\begin{array}{l}0.629^{* *} \\
(0.207)\end{array}$ & $\begin{array}{l}0.627^{* *} \\
(0.202)\end{array}$ & $\begin{array}{l}0.629^{* *} \\
(0.206)\end{array}$ & $\begin{array}{c}0.628^{* *} \\
(0.207)\end{array}$ \\
\hline LTIR_lag1 & $\begin{array}{c}-0.003^{*} \\
(0.002)\end{array}$ & $\begin{array}{c}-0.003^{*} \\
(0.002)\end{array}$ & $\begin{array}{l}-0.002 \\
(0.001)\end{array}$ & $\begin{array}{c}-0.003^{*} \\
(0.002)\end{array}$ \\
\hline Rel_return_lag1 & $\begin{array}{c}0.162 \\
(0.324)\end{array}$ & $\begin{array}{c}0.142 \\
(0.305)\end{array}$ & $\begin{array}{c}0.169 \\
(0.341)\end{array}$ & $\begin{array}{c}0.160 \\
(0.325)\end{array}$ \\
\hline DLoan2GDP_lag1 & $\begin{array}{c}0.153 \\
(0.196)\end{array}$ & $\begin{array}{c}0.150 \\
(0.196)\end{array}$ & $\begin{array}{c}0.140 \\
(0.198)\end{array}$ & $\begin{array}{c}0.140 \\
(0.196)\end{array}$ \\
\hline DLoan2GDP2_lag1 & $\begin{array}{c}-3.144^{*} \\
(1.276)\end{array}$ & $\begin{array}{c}-3.113^{*} \\
(1.298)\end{array}$ & $\begin{array}{c}-3.153^{*} \\
(1.276)\end{array}$ & $\begin{array}{c}-3.090^{*} \\
(1.286)\end{array}$ \\
\hline GBal2GDP_lag1 & $\begin{array}{c}0.303 \\
(0.201)\end{array}$ & $\begin{array}{c}0.310 \\
(0.193)\end{array}$ & $\begin{array}{c}0.337 \\
(0.212)\end{array}$ & $\begin{array}{c}0.311 \\
(0.202)\end{array}$ \\
\hline DLpop_lag1 & $\begin{array}{c}1.443 \\
(0.774)\end{array}$ & $\begin{array}{c}1.499 \\
(0.798)\end{array}$ & $\begin{array}{c}1.405 \\
(0.897)\end{array}$ & $\begin{array}{c}1.639 \\
(0.873)\end{array}$ \\
\hline Dep_ratio_lag1 & $\begin{array}{l}-0.055 \\
(0.129)\end{array}$ & $\begin{array}{l}-0.054 \\
(0.127)\end{array}$ & $\begin{array}{r}-0.030 \\
(0.141)\end{array}$ & $\begin{array}{r}-0.070 \\
(0.141)\end{array}$ \\
\hline Marriage_rate_interp_lag1 & $\begin{array}{c}0.026^{* * *} \\
(0.007)\end{array}$ & $\begin{array}{c}0.026^{* * *} \\
(0.007)\end{array}$ & $\begin{array}{c}0.027^{* * *} \\
(0.007)\end{array}$ & $\begin{array}{c}0.026^{* * *} \\
(0.007)\end{array}$ \\
\hline $\mathrm{R}^{2}$ & 0.095 & 0.095 & 0.094 & 0.096 \\
\hline Num. obs. & 807 & 807 & 807 & 807 \\
\hline
\end{tabular}

${ }^{* * *} p<0.001,{ }^{* *} p<0.01,{ }^{*} p<0.05$ 
Figure 1: Rent regulations by legal origin
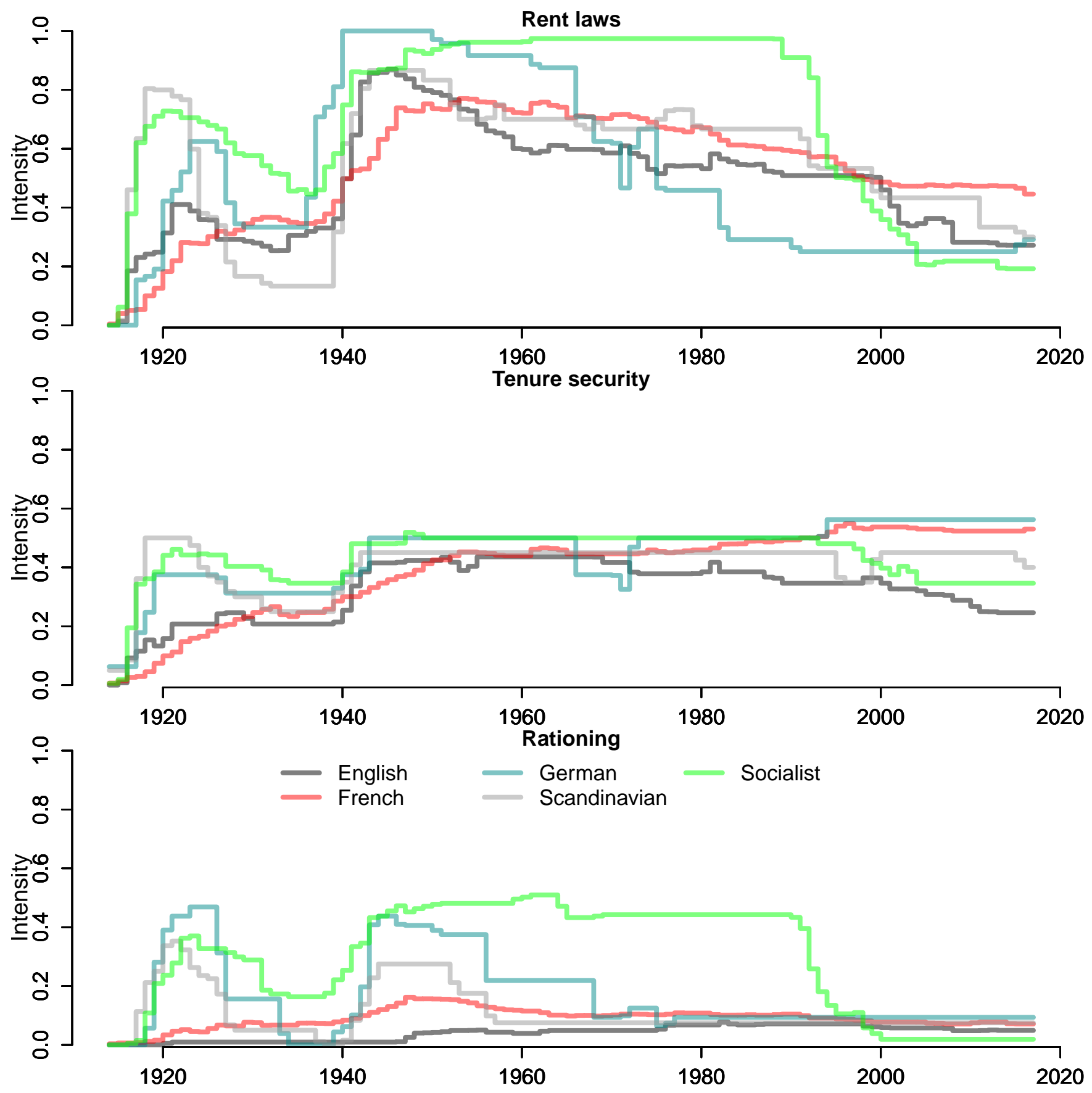
Figure 2: Construction and intensity rent control by legal origin
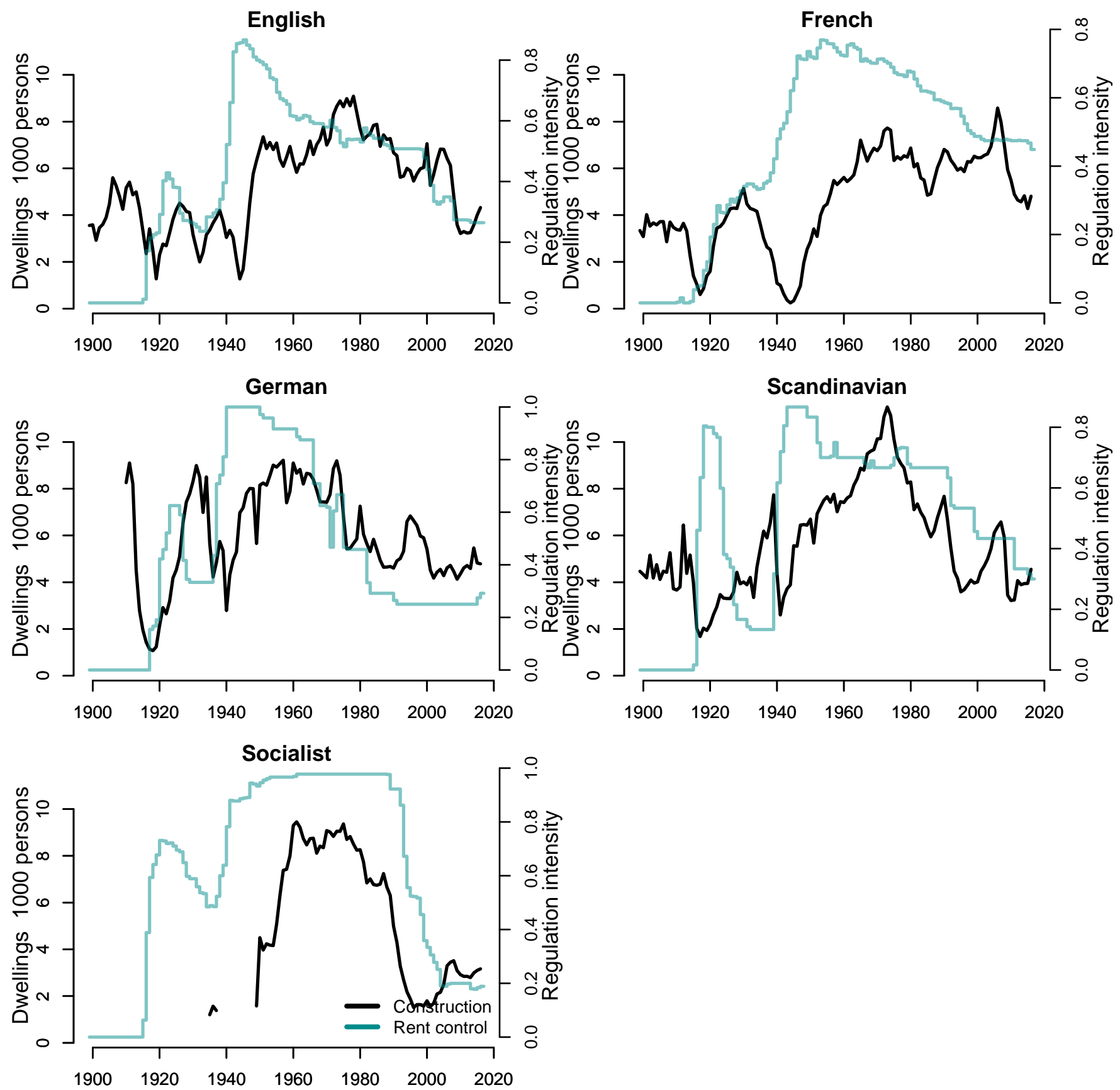
Figure 3: Availability of data for all countries

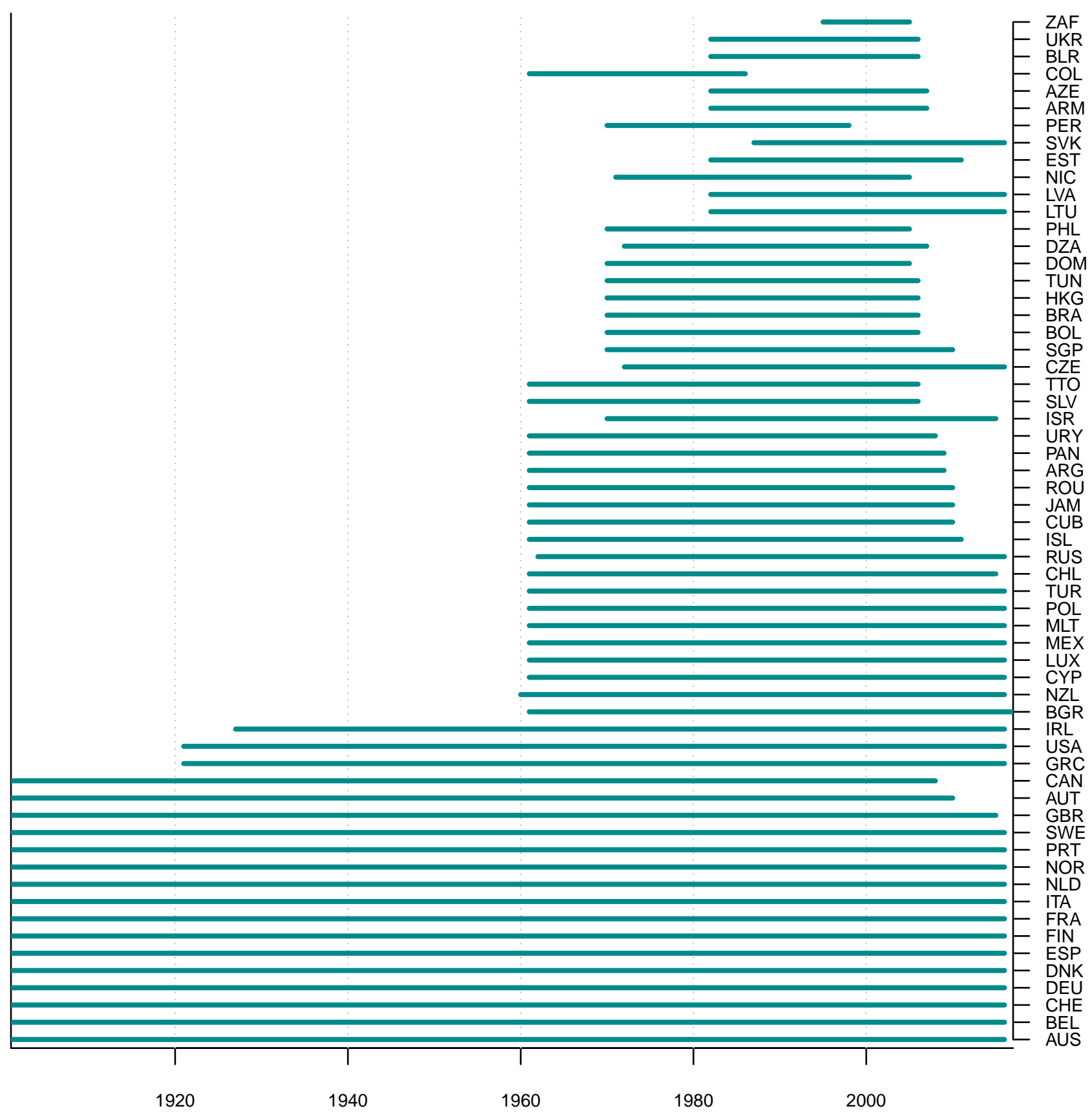


Figure 4: Availability of data for developed countries

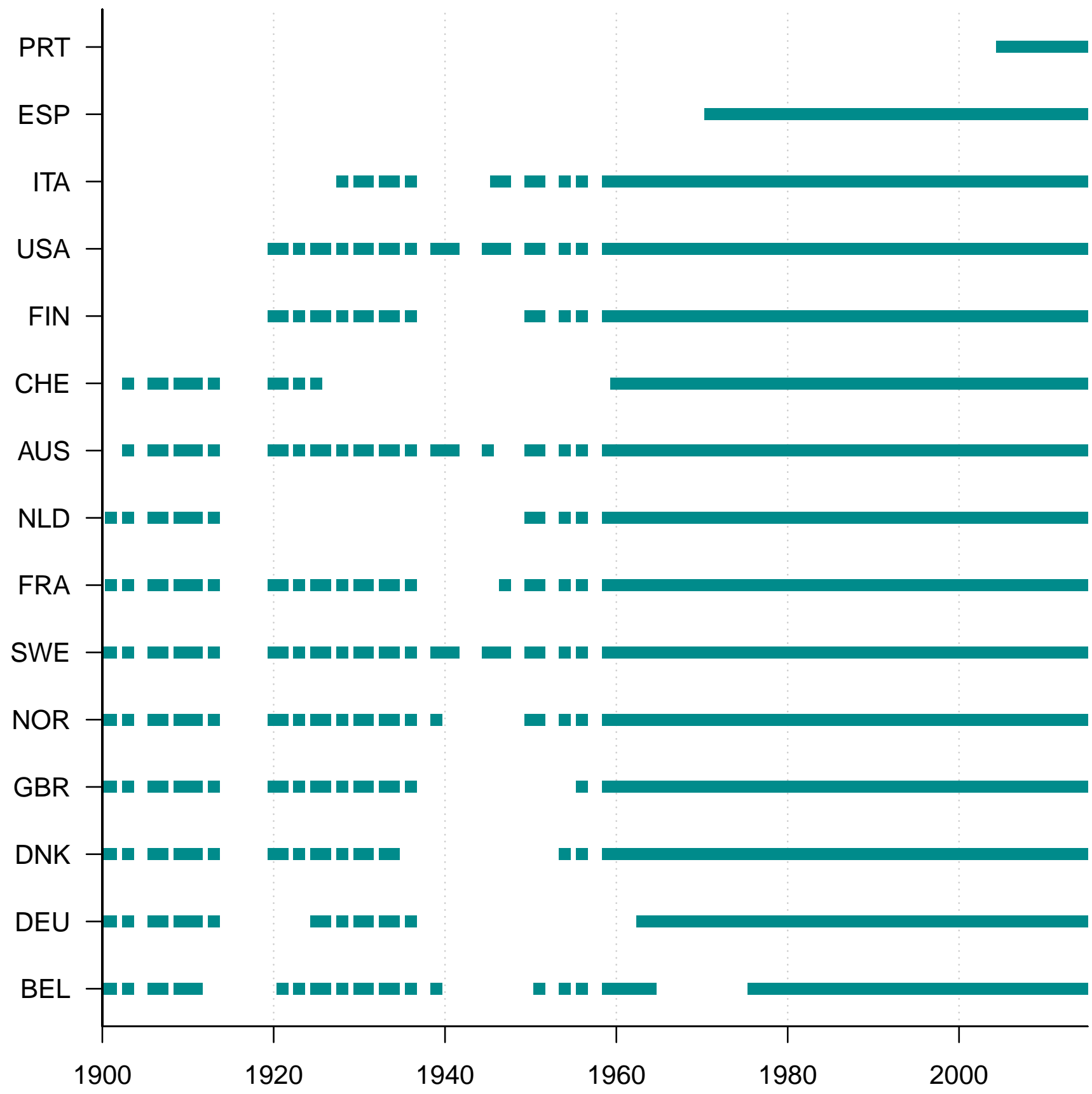


Figure 5: Impact of rent control on residential construction intensity

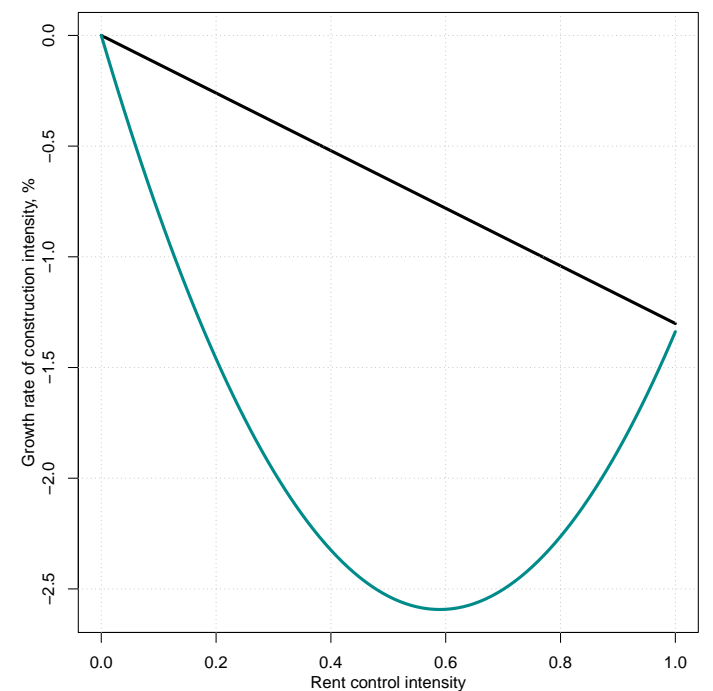

(a) All countries, whole period

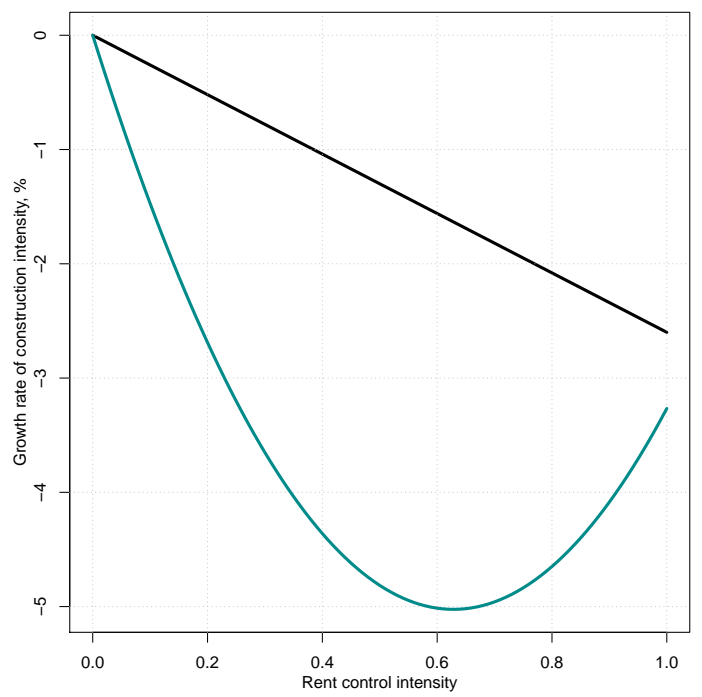

(c) Developed countries, whole period

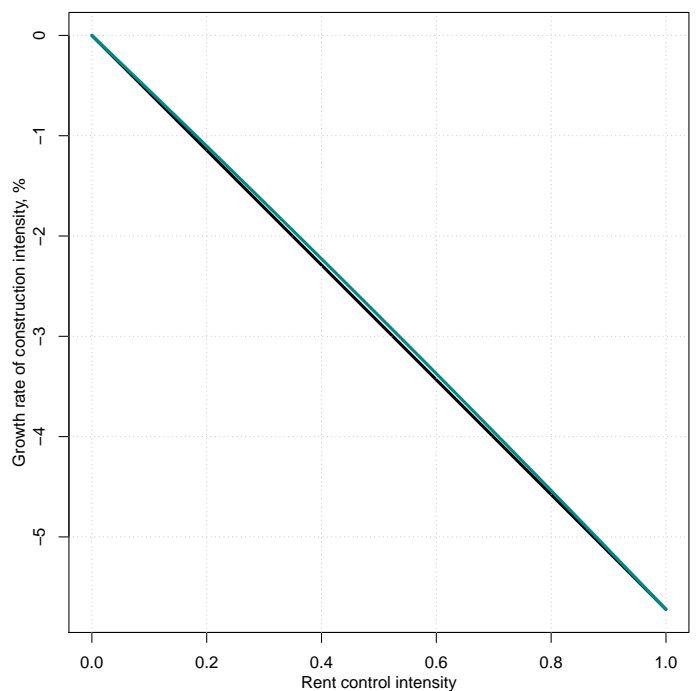

(b) All countries, from 1960

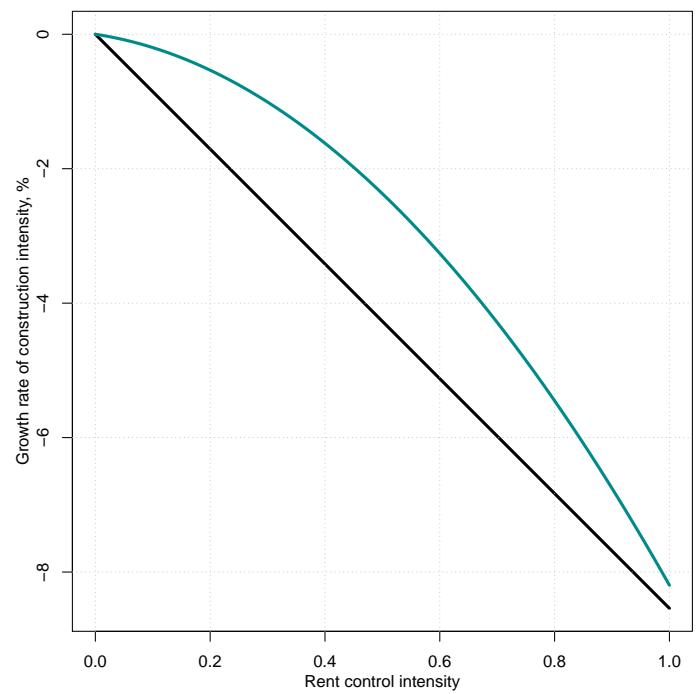

(d) Developed countries, from 1960 